\title{
Staphylococcus aureus Toxins: Promoter or Handicap during Infection?
}

\author{
Bettina Löffler* and Lorena Tuchscherr (D) \\ Institute of Medical Microbiology, Jena University Hospital, 07747 Jena, Germany; \\ Lorena.TuchscherrdeHauschopp@med.uni-jena.de \\ * Correspondence: bettina.loeffler@med.uni-jena.de
}

check for updates

Citation: Löffler, B.; Tuchscherr, L. Staphylococcus aureus Toxins:

Promoter or Handicap during

Infection? Toxins 2021, 13, 287.

https: / / doi.org/10.3390/

toxins13040287

Received: 30 March 2021

Accepted: 7 April 2021

Published: 19 April 2021

Publisher's Note: MDPI stays neutral with regard to jurisdictional claims in published maps and institutional affiliations.

Copyright: (C) 2021 by the authors Licensee MDPI, Basel, Switzerland. This article is an open access article distributed under the terms and conditions of the Creative Commons Attribution (CC BY) license (https:/ / creativecommons.org/licenses/by/ $4.0 /)$.
Staphylococcus aureus is an opportunistic and versatile pathogen that can cause several diseases, which range from acute and destructive, to chronic and difficult-to-treat infections [1,2]. S. aureus colonizes the nasopharynx of many individuals, but this colonization can be the source for infections [3] that vary from superficial mild skin infections to severe diseases, such as pneumonia or osteomyelitis $[4,5]$. In particular, severe staphylococcal infections are associated with significant morbidity and mortality. The ability of $S$. aureus to trigger different types of infection is due to its wide repertoire of virulence factors and infection strategies $[2,6,7]$.

To initiate the infection, S. aureus uses different surface-bound proteins that facilitate the pathogen to attach to host tissue and invade host cells [8-10]. Following adherence and internalization, the bacteria can grow and activate their toxin production largely controlled by global regulators, such as quorum sensing systems [11]. S. aureus can express many molecules, in particular toxins, that harm and destroy host cells [12-16]. During the infection process, the toxins enable the bacteria to destroy and enter deep tissue structures, to obtain nutrition for their growth, and to defend against the immune system [16]. However, after the acute and destructive phase, $S$. aureus bacteria aim for survival within the host $[17,18]$. For bacterial long-term persistence in host tissue, many of the toxins need to be downregulated. In this way, the bacteria are hardly recognized by the immune system and can avoid clearance by phagocytes. Consequently, downregulation of toxins is crucial to silently persist within host cells/tissue for long time periods [18-20].

Taken together, virulence factors, such as toxins, need to be regulated precisely during the course of infection by global regulators, e.g., quorum-sensing systems, which act as a feedback to the surrounding microenvironment [21-25]. Even though staphylococcal toxins are deeply studied, the question remains as to whether and at which stage of the infection a "virulent" strain which expresses a lot of secreted toxins, or a "silent" persisting strain is the real danger for the host.

The purpose of this Special Issue is to publish original research and review articles related to the role of toxins in disease development, the mechanisms of toxin effects in host tissue, the regulation and function of toxins during acute and chronic infections, and toxins as targets for vaccine development and therapeutic interventions. A better understanding of the role of toxins during the different stages of infection may enable us to precisely plan anti-toxic drugs/vaccinations or therapeutic interventions in bacterial regulation.

In two reviews, the importance of $S$. aureus enterotoxins and exotoxins as foodborne intoxications are addressed. The first review highlights the role of staphylococcal enterotoxin $C$ in human and animal health, whereas the second review focusses on measures to avoid food poisoning originating from mastitis or skin infection from ruminants [26,27]. For this, rapid methods to detect $S$. aureus exotoxins in dairy products are required.

The function and effects of toxins that are major virulence factors in serious invasive infections are outlined in the next section. Two original research articles deal with S. aureus leukocidins that efficiently induce cytotoxicity in susceptible leucocytes, whereas these 
effects are highly cell type- and species-specific. In the article by Hodille et al., the effect of leukocidins on bone marrow cells is analyzed to better understand leukopenia, which is described in many clinical cases [28]. In the work by Tromp et al., the host cellular pathways that are activated after the binding of the leukocidins to the cellular receptor of susceptible cells are elucidated [29]. The authors describe post-translational modification pathways that could explain differences in the susceptibility to leukocidins. In a further contribution, the production and release of S. aureus extracellular vesicles (EVs) that are packed with different cytotoxic components and represent a novel bacteria secretory system in response to various stress conditions are analyzed [30]. Finally, the article by Schelin focusses on bacterial regulator networks that control the expression of S. aureus toxins, e.g., superantigens. The authors performed RNAseq analysis, and revealed the role of ClpXP in the complex regulation of $S$. aureus virulence [31].

Two research papers within this Special Issue analyzed the role of toxins in the development of S. aureus pneumonia. Deinhardt-Emmer et al. demonstrated that pneumonia strains exhibit enhanced invasion and cytotoxicity, whereas when the strains were obtained from a viral-bacterial co-infection, these virulence characteristics were not required [32]. Lacoma et al. characterized S. aureus isolates from mechanically ventilated patients. Although the authors performed an extensive analysis, there was no evidence of pathological adaptation related to virulence, resistance, or niche adaptation [4]. From these two papers, we can conclude that almost any S. aureus strain is able to cause a lung infection when the lung is already damaged, e.g., by a preexisting influenza infection or by a mechanical ventilation.

Chronic and difficult-to-treat $S$. aureus infections are major clinical problems which are addressed in this Special Issue as well. One example is chronic rhinosinusitis, and the $S$. aureus leucocidin ED ((LukED) is described as a constant trigger that contributes to disease development [33]. A second well-known disease that is complicated by S. aureus infections is cystic fibrosis (CF). A prospective multicenter study followed the adaptation of $S$. aureus isolates in CF patients. The authors described a decrease in virulence and toxin genes that most likely reflect the bacterial adaptation process towards a persisting phenotype [34]. Additionally, in S. aureus osteomyelitis, the bacteria revealed adaptation strategies largely controlled by the accessory gene regulator (agr) locus, which is extensively reviewed by Butrico et al. [35]. Finally, Wong Fok Lung et al. display the S. aureus metabolic adaptation that is induced by the host immune response and results in bacterial strains adapted for chronicity [36].

We conclude the Special Issue on S. aureus toxins with two manuscripts addressing prophylactic and therapeutic interventions. Shukla et al. propose a statistical method to integrate data on changes in gene expression upon antimicrobial treatments. This method aims to develop a therapeutic regime to not only eliminate bacteria, but also reduce their virulence [37]. Joyner et al. developed a virus-based vaccine that target $S$. aureus toxin (Hla) and attenuates $S$. aureus Hla-mediated pathogenesis [38]. This approach could be part of a multi-component $S$. aureus vaccine in future.

Funding: Our work is funded by MESINFLAME (BMBF grant no. 01EC1901B), Program for innovation and cooperations (ZIM grant no. ZF4561302AW9), by the DFG project LO 1618/6-1, by the Cluster of Excellence EXC 2051 (Project-ID 390713860), by the 588Collaborative Research Center SFB 1278 "PolyTarget" (Project-ID 316213987) and by internal projects from our university (IZKF and JSAM).

Acknowledgments: Bettina Löffler and Lorena Tuchscherr would like to thank all the authors who contributed their work and to the expert peer-reviewers that evaluated all the manuscripts submitted to this Special Issue. Additionally, we would like to thank our special editor Georgia Liu and the editorial support from the MDPI team.

Conflicts of Interest: The authors declare no conflict of interest. 


\section{References}

1. Tong, S.Y.; Davis, J.S.; Eichenberger, E.; Holland, T.L.; Fowler, V.G., Jr. Staphylococcus aureus infections: Epidemiology, pathophysiology, clinical manifestations, and management. Clin. Microbiol. Rev. 2015, 28, 603-661. [CrossRef] [PubMed]

2. Lowy, F.D. Staphylococcus aureus infections. N. Engl. J. Med. 1998, 339, 520-532. [CrossRef] [PubMed]

3. Von Eiff, C.; Becker, K.; Machka, K.; Stammer, H.; Peters, G. Nasal carriage as a source of Staphylococcus aureus bacteremia. Study Group. N. Engl. J. Med. 2001, 344, 11-16. [CrossRef] [PubMed]

4. Lacoma, A.; Laabei, M.; Sánchez-Herrero, J.F.; Young, B.; Godoy-Tena, G.; Gomes-Fernandes, M. Genotypic and Phenotypic Characterization of Staphylococcus aureus Isolates from the Respiratory Tract in Mechanically-Ventilated Patients. Toxins 2021, 13, 122. [CrossRef]

5. $\quad$ Lew, D.P.; Waldvogel, F.A. Osteomyelitis. Lancet 2004, 364, 369-379. [CrossRef]

6. Gordon, R.J.; Lowy, F.D. Pathogenesis of methicillin-resistant Staphylococcus aureus infection. Clin. Infect. Dis. Off. Publ. Infect. Dis. Soc. Am. 2008, 46, S350-S359. [CrossRef]

7. Laabei, M.; Uhlemann, A.C.; Lowy, F.D.; Austin, E.D.; Yokoyama, M.; Ouadi, K.; Feil, E.; Thorpe, H.A.; Williams, B.; Perkins, M.; et al. Evolutionary Trade-Offs Underlie the Multi-faceted Virulence of Staphylococcus aureus. PLoS Biol. 2015, 13, e1002229. [CrossRef]

8. Foster, T.J.; Geoghegan, J.A.; Ganesh, V.K.; Hook, M. Adhesion, invasion and evasion: The many functions of the surface proteins of Staphylococcus aureus. Nat. Rev. Microbiol. 2014, 12, 49-62. [CrossRef]

9. Foster, T.J. The remarkably multifunctional fibronectin binding proteins of Staphylococcus aureus. Eur. J. Clin. Microbiol. Infect. Dis. 2016, 35, 1923-1931. [CrossRef]

10. Grundmeier, M.; Tuchscherr, L.; Bruck, M.; Viemann, D.; Roth, J.; Willscher, E.; Becker, K.; Peters, G.; Loffler, B. Staphylococcal strains vary greatly in their ability to induce an inflammatory response in endothelial cells. J. Infect. Dis. 2010, 201, 871-880. [CrossRef]

11. Tuchscherr, L.; Bischoff, M.; Lattar, S.M.; Noto Llana, M.; Pfortner, H.; Niemann, S.; Geraci, J.; van de Vyver, H.; Fraunholz, M.J.; Cheung, A.L.; et al. Sigma Factor SigB Is Crucial to Mediate Staphylococcus aureus Adaptation during Chronic Infections. PLoS Pathogens 2015, 11, e1004870. [CrossRef]

12. Haslinger, B.; Strangfeld, K.; Peters, G.; Schulze-Osthoff, K.; Sinha, B. Staphylococcus aureus alpha-toxin induces apoptosis in peripheral blood mononuclear cells: Role of endogenous tumour necrosis factor-alpha and the mitochondrial death pathway. Cell. Microbiol. 2003, 5, 729-741. [CrossRef]

13. Haslinger-Loffler, B.; Wagner, B.; Bruck, M.; Strangfeld, K.; Grundmeier, M.; Fischer, U.; Volker, W.; Peters, G.; Schulze-Osthoff, K.; Sinha, B. Staphylococcus aureus induces caspase-independent cell death in human peritoneal mesothelial cells. Kidney Int. 2006, 70, 1089-1098. [CrossRef]

14. Wang, R.; Braughton, K.R.; Kretschmer, D.; Bach, T.H.; Queck, S.Y.; Li, M.; Kennedy, A.D.; Dorward, D.W.; Klebanoff, S.J.; Peschel, A.; et al. Identification of novel cytolytic peptides as key virulence determinants for community-associated MRSA. Nat. Med. 2007, 13, 1510-1514. [CrossRef]

15. Fraunholz, M.; Sinha, B. Intracellular Staphylococcus aureus: Live-in and let die. Front. Cell. Infect. Microbiol. $2012,2,43$. [CrossRef]

16. Otto, M. Staphylococcus aureus toxins. Curr. Opin. Microbiol. 2014, 17, 32-37. [CrossRef]

17. Tuchscherr, L.; Loffler, B.; Buzzola, F.R.; Sordelli, D.O. Staphylococcus aureus adaptation to the host and persistence: Role of loss of capsular polysaccharide expression. Future Microbiol. 2010, 5, 1823-1832. [CrossRef]

18. Tuchscherr, L.; Medina, E.; Hussain, M.; Volker, W.; Heitmann, V.; Niemann, S.; Holzinger, D.; Roth, J.; Proctor, R.A.; Becker, K.; et al. Staphylococcus aureus phenotype switching: An effective bacterial strategy to escape host immune response and establish a chronic infection. Embo Mol. Med. 2011, 3, 129-141. [CrossRef]

19. Tuchscherr, L.; Loffler, B. Staphylococcus aureus dynamically adapts global regulators and virulence factor expression in the course from acute to chronic infection. Curr. Genet. 2015, 62, 15-17. [CrossRef]

20. Tuchscherr, L.; Löffler, B.; Proctor, R.A. Persistence of Staphylococcus aureus: Multiple Metabolic Pathways Impact the Expression of Virulence Factors in Small-Colony Variants (SCVs). Front. Microbiol. 2020, 11, 1028. [CrossRef]

21. Novick, R.P.; Ross, H.F.; Projan, S.J.; Kornblum, J.; Kreiswirth, B.; Moghazeh, S. Synthesis of staphylococcal virulence factors is controlled by a regulatory RNA molecule. EMBO J. 1993, 12, 3967-3975. [CrossRef] [PubMed]

22. Loffler, B.; Tuchscherr, L.; Niemann, S.; Peters, G. Staphylococcus aureus persistence in non-professional phagocytes. Int. J. Med. Microbiol. IJMM 2014, 304, 170-176. [CrossRef] [PubMed]

23. Novick, R.P.; Geisinger, E. Quorum sensing in staphylococci. Ann. Rev. Genet. 2008, 42, 541-564. [CrossRef] [PubMed]

24. Traber, K.E.; Lee, E.; Benson, S.; Corrigan, R.; Cantera, M.; Shopsin, B.; Novick, R.P. agr function in clinical Staphylococcus aureus isolates. Microbiology 2008, 154, 2265-2274. [CrossRef]

25. Novick, R.P. Pathogenicity Islands and Their Role in Staphylococcal Biology. Microbiol. Spectr. 2019, 7. [CrossRef]

26. Etter, D.; Schelin, J.; Schuppler, M.; Johler, S. Staphylococcal Enterotoxin C-An Update on SEC Variants, Their Structure and Properties, and Their Role in Foodborne Intoxications. Toxins 2020, 12, 584. [CrossRef]

27. G Abril, A.; G Villa, T.; Barros-Velazquez, J.; Canas, B.; Sanchez-Perez, A.; Calo-Mata, P.; Carrera, M. Staphylococcus aureus Exotoxins and Their Detection in the Dairy Industry and Mastitis. Toxins 2020, 12, 537. [CrossRef] 
28. Hodille, E.; Plesa, A.; Bourrelly, E.; Belmont, L.; Badiou, C.; Lina, G.; Dumitrescu, O. Staphylococcal Panton-Valentine Leucocidin and Gamma Haemolysin Target and Lyse Mature Bone Marrow Leucocytes. Toxins 2020, 12, 725. [CrossRef]

29. Tromp, A.T.; Van Gent, M.; Jansen, J.P.; Scheepmaker, L.M.; Velthuizen, A.; De Haas, C.J.C.; Van Kessel, K.P.M.; Bardoel, B.W.; Boettcher, M.; McManus, M.T.; et al. Host-Receptor Post-Translational Modifications Refine Staphylococcal Leukocidin Cytotoxicity. Toxins 2020, 12, 106. [CrossRef]

30. Wang, X.; Koffi, P.F.; English, O.F.; Lee, J.C. Staphylococcus aureus Extracellular Vesicles: A Story of Toxicity and the Stress of 2020. Toxins 2021, 13, 75. [CrossRef]

31. Schelin, J.; Cohn, M.T.; Frisk, B.; Frees, D. A Functional ClpXP Protease is Required for Induction of the Accessory Toxin Genes, tst, sed, and sec. Toxins 2020, 12, 553. [CrossRef] [PubMed]

32. Deinhardt-Emmer, S.; Haupt, K.F.; Garcia-Moreno, M.; Geraci, J.; Forstner, C.; Pletz, M.; Ehrhardt, C.; Loffler, B. Staphylococcus aureus Pneumonia: Preceding Influenza Infection Paves the Way for Low-Virulent Strains. Toxins 2019, 11, 734. [CrossRef] [PubMed]

33. Poddighe, D.; Vangelista, L. Staphylococcus aureus Infection and Persistence in Chronic Rhinosinusitis: Focus on Leukocidin ED. Toxins 2020, 12, 678. [CrossRef]

34. Lange, J.; Heidenreich, K.; Higelin, K.; Dyck, K.; Marx, V.; Reichel, C.; van Wamel, W.; Reijer, M.d.; Gorlich, D.; Kahl, B.C. Staphylococcus aureus Pathogenicity in Cystic Fibrosis Patients-Results from an Observational Prospective Multicenter Study Concerning Virulence Genes, Phylogeny, and Gene Plasticity. Toxins 2020, 12, 279. [CrossRef] [PubMed]

35. Butrico, C.E.; Cassat, J.E. Quorum Sensing and Toxin Production in Staphylococcus aureus Osteomyelitis: Pathogenesis and Paradox. Toxins 2020, 12, 516. [CrossRef]

36. Prince, A.; Wong Fok Lung, T. Consequences of Metabolic Interactions during Staphylococcus aureus Infection. Toxins 2020, 12,581 .

37. Shukla, S.K.; Carter, T.C.; Ye, Z.; Pantrangi, M.; Rose, W.E. Modeling of Effective Antimicrobials to Reduce Staphylococcus aureus Virulence Gene Expression Using a Two-Compartment Hollow Fiber Infection Model. Toxins 2020, 12, 69. [CrossRef]

38. Joyner, J.A.; Daly, S.M.; Peabody, J.; Triplett, K.D.; Pokhrel, S.; Elmore, B.O.; Adebanjo, D.; Peabody, D.S.; Chackerian, B.; Hall, P.R. Vaccination with VLPs Presenting a Linear Neutralizing Domain of S. aureus Hla Elicits Protective Immunity. Toxins 2020, 12, 450. [CrossRef] 